\title{
The effect of genotype on the chemical and fatty acid composition of the Quadriceps femoris muscle in extensively fattened lambs
}

\author{
DAVID ZAPLETAL'1, JAN KUCHTÍK² and IGOR DOBEŠ²
}

${ }^{1}$ Faculty of Veterinary Hygiene and Ecology, University of Veterinary and Pharmaceutical Sciences Brno, Czech Republic, ${ }^{2}$ Faculty of Agronomy, Mendel University in Brno, Czech Republic

\begin{abstract}
The aim of the experiment was to define the effect of a Suffolk-sired genotype on the chemical composition and fatty acid profile of the Quadriceps femoris muscle in fattened lambs reared under organic farming conditions. Three different genotypes of Suffolk-sired crossbreds were included in the experiment: F1 Suffolk-Charollais (SF $50 \mathrm{CH} 50, n=10$ ), F11 Suffolk-Charollais (SF $75 \mathrm{CH} 25, \mathrm{n}=10$ ) and F1 Suffolk-Improved Walachian (SF 50 IW 50, n=10). The genotype did not have any effect on age at slaughter, average daily gain or carcass dressing percentages. However, the SF $75 \mathrm{CH} 25$ lambs displayed a lower live weight at slaughter $(P<0.05)$, lower cold carcass weight $(P<0.05)$ and lower protein content in muscle $(P<0.05)$ than both of the other genotypes. They also had a lower content of kidney fat compared to the $\mathrm{SF} 50 \mathrm{CH}$ $50(P<0.01)$. The F11 Suffolk-Charollais lambs showed a higher proportion of $\mathrm{C} 12: 0(P<0.01)$, C14:0 $(P<0.01)$ and $C 16: 0(P<0.05)$ than the other two genotypes. A higher proportion of $C 18: 0$ was found in the SF 50 CH 50 lambs $(P<0.05)$. The total content of saturated fatty acids (SFA) was higher in the SF $75 \mathrm{CH} 25$ crossbreds $(P<0.05)$. The genotype also affected the content of $\mathrm{C} 16: 1$ having its highest presence in the SF $75 \mathrm{CH} 25$ lambs while the lowest presence was found in the SF $50 \mathrm{CH} 50$ lambs $(P<0.01)$. Between these two genotypes there were also found different proportions of $C 18: 1$ having its higher presence in SF 50 CH 50 lambs $(P<0.05)$. Moreover, the IW type lambs had a lower SFA proportion and lower values of atherogenic and thrombogenic indexes and a higher polyunsaturated/saturated fatty acid (P/S) ratio in their meat than lambs of the $\mathrm{CH}$ genotypes $(P<0.05)$. As for crossing between the Suffolk and Charollais breeds, a favourable fatty acids profile of meat was observed in the F1 crossbred as compared to the F11 crossbred.
\end{abstract}

Keywords: sheep, meat, fatty acids, Suffolk-sired crossbreds, organic farming

\section{Zusammenfassung}

\section{Der Einfluss des Genotyps auf die chemische und Fettsäurezusammensetzung des Musculus quadriceps femoris (Oberschenkelmuskels) bei extensiv gemästeten Lämmern}

Das Ziel des Experimentes war, den Effekt eines von Suffolk-Vatertieren hervorgebrachten Genotyps auf die chemische Zusammensetzung und das Fettsäureprofil des Musculus 
quadriceps femoris in den gemästeten Lämmern zu definieren, die unter Bedingungen der ökologischen Landwirtschaft aufgezogen wurden. Drei verschiedene Genotypen von Suffolk-Vatertier-Kreuzungen waren an dem Experiment beteiligt: F1 Suffolk-Charollais (SF 50 CH 50, n=10), F11 Suffolk-Charollais (SF 75 CH 25, n=10) und F1 Suffolk - Walachen Schaf (SF 50 WS 50, n=10). Der Genotyp hatte keinen Einfluß auf das Schlachtalter, die täglichen Zunahmen oder auf die Schlachtausbeute. Jedoch zeigten die SF 75 CH 25 Lämmer ein niedrigeres Lebendgewicht am Schlachttag $(P<0.05)$, niedrigere Ausschlachtung $(P<0.05)$ und niedrigeren Proteingehalt im Muskel $(P<0.05)$ als die beiden anderen Genotypen. Auch hatten sie einen geringeren Anteil an Nierenfett im Vergleich zu den SF $50 \mathrm{CH} 50(P<0.01)$. Die F11 Suffolk-Charollais-Lämmer zeigten einen höheren Anteil C12:0 $(P<0.01), C 14: 0(P<0.01)$ und C16:0 $(P<0.05)$ als die beiden anderen Genotypen. Ein höherer Anteil C18:0 wurde in den SF 50 CH 50 Lämmern gefunden $(P<0.05)$. Der Gesamtinhalt von SFA war bei den SF 75 CH 25 Kreuzungen höher $(P<0.05)$. Der Genotyp beeinflusste auch den Inhalt in C16:1 $(P<0.01)$ und C18:1 $(P<0.05)$. Außerdem hatten die WS Lämmer einen niedrigeren SFA-Anteil und niedrigere Werte bei den Atherogenen und Thrombogenen Indizes und ein höheres P/S Verhältnis in ihrem Fleisch als Lämmer der $\mathrm{CH}-$ Genotypen $(P<0.05)$. Was die Kreuzung zwischen den Suffolk- und Charollaisherkünften betrifft, wurde ein vorteilhafteres Fettsäureprofil des Fleisches bei den F1-Kreuzungen im Vergleich mit den F11-Kreuzungen beobachtet.

Schlüsselwörter: Schaf, Lämmer, Fettsäuren, Suffolk-Vatertier-Kreuzungen, ökologische Landwirtschaft

\section{Introduction}

The Suffolk (SF) and Charollais (CH) breeds are among the most important breeds of sheep reared in the Czech Republic. A national report on sheep performance recording states that in 2007 the SF purebreds made up the largest segment of the sheep population and $\mathrm{CH}$ purebreds were the third largest. On the other hand, the original Improved Walachian (IW) sheep, a very important breed in the Slovak Republic, is currently a minor breed in the Czech Republic. The stocks of this triple-purpose breed are located mainly in its place of origin Walachian region - while one part of its population is milked and the other part is designated for meat production.

As for the meat production of IW sheep, they are most frequently crossed with meat type rams, mainly with Suffolk sires. In the Czech Republic, the Suffolk sheep are reared in all production regions, either as purebreds, or as a sire breed crossed with dual and multipurpose breeds in order to improve the growth rate and carcass value (mainly the meatiness) of lambs. In contrast, the $\mathrm{CH}$ sheep are reared in more favourable climatic conditions (at altitudes up to $500 \mathrm{~m}$ ) and usually as purebreds. However, recently, the $\mathrm{CH}$ breed has begun spreading to sub-mountainous (in our case) and mountainous regions. Generally, it can be stated that newborn CH lambs are typically less woolly (particularly in the distal part of body), which, in unfavourable climatic conditions such as low temperatures, long-term rainfall, and snow even in early May, can lead to a decreased performance, algidity or even death. Taking into account the above stated facts, many farms in sub-mountainous and mountainous regions have started to cross $\mathrm{CH}$ ewes with Suffolk sires in order to grading up to SF breed. 
Recently, the profile of fatty acids in the human diet has received increased attention due to their impact on human health. Lamb fat deposition and composition of fatty acids (FA) can be influenced by many factors including breed, gender, age/body weight, fatness, depot site, environmental conditions, diet and rearing management (NÜRNBERG et al. 1998, NÜRNBERG et al. 2001, SZUMACHER-STRABEL et al. 2001, GRUSZECKI et al. 2004). Also, the significant effects of cross-breeding on the FA composition of lamb meat have been confirmed by SNOWDER and DUCKETT (2003), SALVATORI et al. (2004) and BORYS et al. (2007). There are only a few studies evaluating the nutritional quality of lamb meat fattened under organic farming conditions (CIFUNI et al. 2003, NÜRNBERG et al. 2006, ANGOOD et al. 2008), and there is no information about the FA composition of meat in IW type lambs.

The aim of this study was to define the effect of the Suffolk-sired genotype on the chemical composition and fatty acid profile of the Quadriceps femoris muscle in fattened lambs reared in organic farming conditions.

\section{Material and methods}

The experiment was carried out at an organic sheep farm in Růžd"ka located in northern Moravia in the Czech Republic (pastures are situated at the altitude of 365 to $738 \mathrm{~m}$ above sea level with an average annual temperature of $7.0^{\circ} \mathrm{C}$ and precipitation of $880 \mathrm{~mm}$ ). The animals used in the experiment were 30 single male lambs descended from three-year old ewes. Three different genotypes of Suffolk-sired crossbreds were included in the experiment: F1 Suffolk-Charollais (SF 50 CH 50, n=10), F11 Suffolk-Charollais (SF 75 CH 25, n=10), and F1 Suffolk-Improved Walachian (SF 50 IW 50, $\mathrm{n}=10$ ). All lambs were born indoors during the second half of January, 2007. During the period from their birth until the end of April, all of the lambs were reared indoors with their mothers. The daily feeding ration of the lambs consisted of the mother's milk (ad libitum), meadow hay (ad libitum) and organic mineral lick (ad libitum). The lambs were weaned during the last ten days of April. From May until slaughter, all of the lambs were grazed in an extensive permanent pasture under organic conditions. The daily feeding ration for the weaned lambs consisted of grass (ad libitum), meadow hay (ad libitum) and organic mineral lick (ad libitum). During the experiment, all of the lambs were reared in one flock under identical conditions without any discernible differences in nutrition or management.

The SF $75 \mathrm{CH} 25$ lambs were slaughtered at an average age of 150 days and at a live weight of $32.1 \mathrm{~kg}$. The SF $50 \mathrm{CH} 50$ lambs were slaughtered at an average age of 181 days at a live weight of $38.4 \mathrm{~kg}$. The SF 50 IW 50 lambs were slaughtered at an average age of 174 days at a live weight of $37.1 \mathrm{~kg}$. The meat production characteristics such as live weight (LWS), age at slaughter and average daily gain (ADG) were evaluated on the day of slaughter. On the following day, after a chilling period of approximately $24 \mathrm{~h}$, the cold carcass weight (CCW), dressing percentage and the content of kidney fat were evaluated and samples of the Quadriceps femoris muscle were collected. The kidney fat percentage was determined as the ratio of the weight of kidney fat to the weight of CCW.

The dry matter content was determined in homogenized meat samples mixed with dry sea sand; the samples were pre-dried at the temperature of $60^{\circ} \mathrm{C}$ for two hours and then dried at $105^{\circ} \mathrm{C}$ for $6 \mathrm{~h}$. The protein content was calculated as percentage of nitrogen multiplied by 
6.25. The ash content was determined by burning in a laboratory furnace at the temperature of $550^{\circ} \mathrm{C}$ for $8 \mathrm{~h}$. The fat content was determined by extraction with diethyl ether in Soxhlet extractor for $6 \mathrm{~h}$. The extraction was performed without acid hydrolysis.

The FA were methylated with sodium methylate and subsequently with boron trifluoride in methanol. The FAME were analysed on a gas chromatograph CHROM 5 (Laboratorni pristroje, Prague, $\mathrm{CR}$ ) with a flame ionizing detector (FID). The temperature of the column rose from the initial $100^{\circ} \mathrm{C}$ up to $250^{\circ} \mathrm{C}$. The carrier gas was nitrogen. The injector and detector (FID) were set at $280^{\circ} \mathrm{C}$. For each analysis $2 \mu$ of the sample was injected into the gas chromatograph equipment. The analysed FAME were identified on the basis of elution times and compared with elution times of standard methyl esters of fatty acids. For identification, the reference sample of FAME Mix 37 was used. The Cl-105 integrator (Laboratorni pristroje, Prague, CR) was used for quantitative evaluations of chromatographic analysis. The result of the evaluations is the content (\%) of fatty acids. Atherogenic and thrombogenic indices were calculated according to ULBRICHT and SOUTHGATE (1991) as follow:

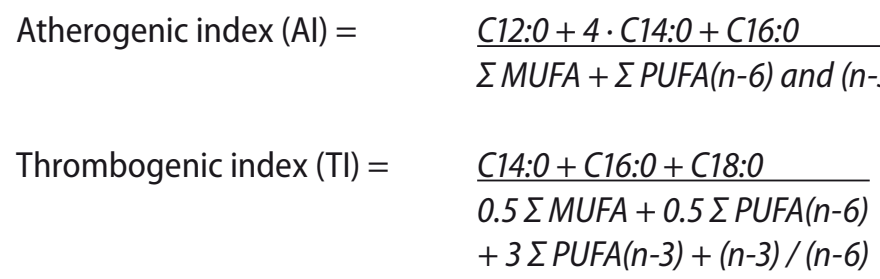

A statistical analysis was carried out using STATISTICA CZ version 6. ANOVA analysis was applied to study the differences in the animal live weight, age at slaughter, gain, carcass traits and chemical composition of the Quadriceps femoris muscle as three independent groups of genotypes. When the analysis of variance showed significant differences between the groups, the Fisher's LSD test was applied. The effect of genotype on the differences in the FA composition and FA ratios of muscle tissue was studied by analysis of covariance (ANOVA), where the live weight at slaughter was included as covariate. The differences were considered significant if $P<0.05$.

\section{Results}

The age and live weight at slaughter, average daily gain, carcass traits (cold weight, content of kidney fat) and the basic chemical composition of the Quadriceps femoris muscle are summarized in Table 1. SF 75 CH 25 lambs displayed a significantly lower LWS and CCW than both of the other genotypes and also a lower content of kidney fat compared to the SF 50 $\mathrm{CH} 50$ lambs. The genotype did not have any significant effect on ADG or carcass dressing percentages. A slightly lower average age at the slaughter of the $\mathrm{SF} 75 \mathrm{CH} 25$ crossbreds was found to be insignificant as well.

Concerning the chemical composition of the Quadriceps femoris muscle, only the content of protein was significantly affected by the different genotypes, and the SF $75 \mathrm{CH} 25$ crossbreds had the lower level $(P \leq 0.05)$. A somewhat higher presence of intramuscular (IM) fat in SF 75 $\mathrm{CH} 25$ lambs when compared to both of the other genotypes was not statistically confirmed. 
Table 1

The effect of genotype on the growth, carcass quality traits and chemical composition of the Quadriceps femoris muscle

Der Effekt der Genotypen auf das Wachstum, die Schlachtkörperqualitätsmerkmale und chemische Zusammensetzung des Quadriceps Femoris

\begin{tabular}{|c|c|c|c|}
\hline \multirow[t]{3}{*}{ Traits } & \multicolumn{3}{|c|}{ Genotype } \\
\hline & \multirow{2}{*}{$\begin{array}{c}\text { SF } 75 \text { CH } 25 \\
\bar{x} \pm \text { SEM }\end{array}$} & \multirow{2}{*}{$\begin{array}{c}\text { SF } 50 \text { CH } 50 \\
\bar{x} \pm \text { SEM }\end{array}$} & \multirow{2}{*}{$\begin{array}{c}\text { SF } 50 \text { IW } 50 \\
\bar{x} \pm \text { SEM }\end{array}$} \\
\hline & & & \\
\hline Birth weight, kg & $3.8 \pm 0.38$ & $4.1 \pm 0.26$ & $4.1 \pm 0.33$ \\
\hline LWS, kg & $32.1^{\mathrm{A}, \mathrm{a}} \pm 1.08$ & $38.4^{B} \pm 1.70$ & $37.1^{\mathrm{b}} \pm 1.67$ \\
\hline Age at slaughter, day & $150.0 \pm 16.15$ & $181.0 \pm 10.93$ & $173.8 \pm 12.78$ \\
\hline ADG, g/day & $198.3 \pm 12.09$ & $190.8 \pm 4.33$ & $193.9 \pm 9.16$ \\
\hline CCW, kg & $14.1^{\mathrm{A}, \mathrm{a}} \pm 0.49$ & $16.8^{\mathrm{B}} \pm 0.59$ & $16.0^{b} \pm 0.61$ \\
\hline Dressing percentage, $\%$ & $43.79 \pm 0.333$ & $44.10 \pm 0.890$ & $43.27 \pm 0.941$ \\
\hline Kidney fat, \% & $0.11^{A} \pm 0.021$ & $0.29^{B} \pm 0.051$ & $0.20 \pm 0.022$ \\
\hline \multicolumn{4}{|c|}{ Quadriceps femoris composition } \\
\hline Dry matter, g/kg & $234.26 \pm 1.874$ & $231.74 \pm 2.602$ & $232.22 \pm 2.826$ \\
\hline IM fat, $\mathrm{g} / \mathrm{kg}$ & $26.93 \pm 1.530$ & $21.20 \pm 2.275$ & $22.81 \pm 3.114$ \\
\hline Protein, $\mathrm{g} / \mathrm{kg}$ & $192.43^{\mathrm{a}} \pm 1.939$ & $197.91^{b} \pm 1.025$ & $197.01^{b} \pm 1.365$ \\
\hline Ash, g/kg & $11.23 \pm 0.011$ & $11.24 \pm 0.009$ & $11.49 \pm 0.005$ \\
\hline
\end{tabular}

${ }_{\mathrm{A}, \mathrm{B}} \mathrm{P}<0.01, \quad{ }^{\mathrm{a}}, \mathrm{b} P<0.05$, LWS live weight at slaughter, ADG average daily gain, CCW cold carcass weight, IM intramuscular

The results for the fatty acid profile, fatty acid ratios and indexes of the Quadriceps femoris muscle are presented in Table 2. The SF 75 CH 25 lambs showed a significantly higher proportion of lauric acid (C12:0), myristic acid (C14:0) and palmitic acid (C16:0) compared to the SF 50 CH 50 and SF 50 IW 50 lambs, while a higher proportion of stearic acid (C18:0) was found in the SF $50 \mathrm{CH} 50$ lambs. The total content of saturated fatty acids (SFA) was significantly higher in the $\mathrm{SF} 75 \mathrm{CH} 25$ crossbreds, whereas the content between the SF $50 \mathrm{CH}$ 50 and SF 50 IW 50 genotypes did not differ.

The total content of monounsaturated fatty acids (MUFA) did not vary among the evaluated genotypes. However, the genotypes significantly affected the content of palmitoleic acid (C16:1) having its highest presence in the SF 75 CH 25 lambs while the lowest presence was found in the SF $50 \mathrm{CH} 50$ lambs. Between these two genotypes there were also found different proportions of C18:1.

In polyunsaturated fatty acids (PUFA) proportion, the SF 50 IW 50 lambs had higher contents of linoleic acid (C18:2-n6), arachidonic acid (C20:4-n6) and docosatetraenoic acid (C22:4-n6) than the SF 50 CH 50 lambs. The total content of PUFA was not affected by the different genotypes of the Suffolk crossbreds.

The SF 50 IW 50 lambs showed significantly higher values $(P \leq 0.05)$ of the $P / S$ ratio, the sum of $n-6$ PUFA and the $n-6 / n-3$ PUFA ratio compared to the SF $50 \mathrm{CH} 50$ lambs.

A significantly higher atherogenic index (Al) was found in the SF $75 \mathrm{CH} 25$ crossbreds and a lower thrombogenic index (TI) in the SF 50 IW 50 crossbreds. The SF 50 CH 50 genotype displayed a significantly lower level of $\Delta^{9}$-desaturase (16) index. 
Table 2

The effect of the genotype on the fatty acid profile ( $\mathrm{g} / 100 \mathrm{~g}$ of total fatty acids), fatty acid ratios and indexes of the Quadriceps femoris muscle composition

Der Effekt der Genotypen auf das Fettsäurenprofil (g/100g des Gesamtinhalts), das Fettsäurenverhältnis und die Indizes des Quadriceps Femoris

\begin{tabular}{|c|c|c|c|}
\hline \multirow[t]{3}{*}{ Fatty acid } & \multicolumn{3}{|c|}{ Genotype } \\
\hline & SF $75 \mathrm{CH} 25$ & SF 50 CH 50 & SF 50 IW 50 \\
\hline & $\bar{x} \pm$ SEM & $\bar{x} \pm$ SEM & $\bar{x} \pm S E M$ \\
\hline C12:0 & $0.32^{\mathrm{B}} \pm 0.047$ & $0.18^{A} \pm 0.033$ & $0.19^{A} \pm 0.023$ \\
\hline C14:0 & $4.08^{B} \pm 0.399$ & $2.63^{A} \pm 0.365$ & $2.80^{\mathrm{A}} \pm 0.294$ \\
\hline $\mathrm{C} 16: 0$ & $23.70^{\mathrm{b}} \pm 0.716$ & $21.93^{\mathrm{a}} \pm 0.657$ & $21.82^{\mathrm{a}} \pm 0.670$ \\
\hline C18:0 & $19.86^{\mathrm{a}} \pm 0.737$ & $22.25^{b} \pm 0.848$ & $20.43^{\mathrm{a}} \pm 0.746$ \\
\hline $\mathrm{C} 16: 1$ & $2.40^{C} \pm 0.092$ & $2.01^{A} \pm 0.112$ & $2.17^{B} \pm 0.114$ \\
\hline C18:1 & $38.63^{\mathrm{a}} \pm 0.703$ & $41.21^{b} \pm 0.541$ & $41.03^{a, b} \pm 1.158$ \\
\hline C20:1 & $0.44 \pm 0.028$ & $0.54 \pm 0.053$ & $0.50 \pm 0.035$ \\
\hline C18:2-n6 & $5.61^{a, b} \pm 0.127$ & $4.82^{\mathrm{a}} \pm 0.205$ & $5.87^{b} \pm 0.511$ \\
\hline C18:3-n6 & $0.03 \pm 0.003$ & $0.04 \pm 0.005$ & $0.03 \pm 0.003$ \\
\hline C18:3-n3 & $2.26 \pm 0.153$ & $2.05 \pm 0.108$ & $2.17 \pm 0.149$ \\
\hline C20:4-n6 & $1.11^{\mathrm{a}, \mathrm{b}} \pm 0.076$ & $1.00^{\mathrm{a}} \pm 0.087$ & $1.35^{b} \pm 0.157$ \\
\hline$C 20: 5-n 3$ & $0.51 \pm 0.034$ & $0.49 \pm 0.057$ & $0.58 \pm 0.064$ \\
\hline C22:4-n6 & $0.07^{\mathrm{a}, \mathrm{b}} \pm 0.006$ & $0.05^{\mathrm{a}} \pm 0.006$ & $0.09^{b} \pm 0.018$ \\
\hline C22:5-n6 & $0.02 \pm 0.004$ & $0.02 \pm 0.003$ & $0.02 \pm 0.003$ \\
\hline C22:5-n3 & \pm 0.037 & $0.62 \pm 0.053$ & \pm 0.067 \\
\hline C22:6-n3 & $0.19 \pm 0.012$ & $0.16 \pm 0.018$ & $0.18 \pm 0.015$ \\
\hline SFA & $47.97^{\mathrm{B}, \mathrm{b}} \pm 0.679$ & $46.99^{\mathrm{a}} \pm 0.381$ & $45.24^{\mathrm{A}} \pm 0.606$ \\
\hline MUFA & $41.47 \pm 0.643$ & $43.76 \pm 0.541$ & $43.70 \pm 1.116$ \\
\hline PUFA & \pm 0.265 & $9.26 \pm 0.493$ & $11.06 \pm 0.943$ \\
\hline UFA & $52.03^{\mathrm{A}} \pm 0.679$ & $53.01^{\mathrm{a}} \pm 0.381$ & $54.76^{\mathrm{B}, \mathrm{b}} \pm 0.606$ \\
\hline $\mathrm{P} / \mathrm{S}$ & $0.22^{\mathrm{a}, \mathrm{b}} \pm 0.007$ & $0.20^{\mathrm{a}} \pm 0.011$ & $0.24^{b} \pm 0.021$ \\
\hline n6 & $6.84^{\mathrm{a}, \mathrm{b}} \pm 0.162$ & $5.94^{\mathrm{a}} \pm 0.295$ & $7.36^{b} \pm 0.674$ \\
\hline n3 & $3.73 \pm 0.147$ & $3.32 \pm 0.222$ & $3.70 \pm 0.278$ \\
\hline$n-6 / n-3$ & $1.85^{\mathrm{a}, \mathrm{b}} \pm 0.064$ & $1.82^{\mathrm{a}} \pm 0.089$ & $1.98^{b} \pm 0.062$ \\
\hline C18:2-n6/C18:3-n3 & $2.54^{\mathrm{a}, \mathrm{b}} \pm 0.143$ & $2.39^{\mathrm{a}} \pm 0.130$ & $2.71^{b} \pm 0.123$ \\
\hline Atherogenic index & $0.78^{\mathrm{B}, \mathrm{b}} \pm 0.055$ & $0.65^{\mathrm{a}} \pm 0.057$ & $0.61^{A} \pm 0.038$ \\
\hline Thrombogenic index & $1.33^{b} \pm 0.037$ & $1.33^{b} \pm 0.034$ & $1.22^{\mathrm{a}} \pm 0.032$ \\
\hline$\Delta 9$-desaturase (16) index & $9.20^{\mathrm{B}} \pm 0.119$ & $8.36^{A} \pm 0.259$ & $9.04^{B} \pm 0.288$ \\
\hline$\Delta 9$-desaturase (18) index & $66.09 \pm 0.865$ & $65.00 \pm 1.004$ & $66.74 \pm 1.045$ \\
\hline
\end{tabular}

\section{Discussion}

Genotype had a significant effect on live weight at slaughter, respectively on cold carcass weight, while the intensity of growth did not vary. So, a lower LWS of the SF $75 \mathrm{CH} 25$ lambs was brought about by their insignificantly lower age at slaughter. Generally, it can be stated that the ADGs of all Suffolk-sired genotypes were relatively low as compared to results for Suffolk crossbreds published by BIANCHI et al. (2003) and SNOWDER and DUCKETT (2003). The lower ADGs can be explained by the extensive nutrition and relatively unfavourable 
climatic conditions like high rainfall and low night temperatures. On the other hand, the low ADGs of the Suffolk crosses in our experiment are in accordance with the findings of FANTOVÁ and ČISLÍKOVSKÁ (1991) and DA CUNHA et al. (2000).

The results do not indicate any significant effect of crossbreeding on carcass dressing percentage which is in agreement with results reported by KUCHTíK and HORÁK (2001) and GUTIÉRREZ et al. (2005). In contrast, KREMER et al. (2004) reported a significant effect of genotype on dressing percentage in lambs. As for kidney fat, the SF $50 \mathrm{CH} 50$ lambs showed a higher level as compared to the SF $75 \mathrm{CH} 25$ lambs, which was likely attributed to the different LWS of these genotypes. The weight of kidney fat varied from 110 to $290 \mathrm{~g}$, which corresponds to the findings of ARCHIMEDE et al. (2008) in ovine Martinik lambs. In addition, in their experiment the level of kidney fat increased progressively with the inclusion ratio of dietary concentrates.

The contents of dry matter, IM fat and ash in the Quadriceps femoris muscle were not affected by genotype. The dry matter content was almost identical in all Suffolk-sired genotypes, while its values were in accordance with the findings of KUCHTíK et al. (1996) and FOTI et al. (2005). The IM fat content varied from 2.1 to $2.7 \%$. Similar values for IM fat in various muscles of the Charollais and Stavropol Merino lambs were also presented by KUCHTíK et al. (1996). If the IM fat content is less than $5 \%$, the meat can be regarded as lean meat (FOOD ADVISORY COMMITTEE, 1990). Genotype significantly affected the protein content of the Quadriceps femoris muscle. A lower presence of protein was found in the SF $75 \mathrm{CH} 25$ lambs compared to the SF $50 \mathrm{CH} 50$ and IW type crossbreds. The protein content in the Quadriceps femoris muscle of Suffolk-sired crossbreds in our experiment corresponds to the findings of FOTI et al. (2005) in the Longissimus dorsi muscle.

In order to eliminate the effect of varying live weight on FA composition, the LWS was included as a covariant in the statistical model (NÜRNBERG et al. 1999). Genotype affected the composition of saturated fatty acids. The content of C12:0, C14:0, C16:0 and total SFA was significantly higher in the SF $75 \mathrm{CH} 25$ crossbreds compared to both of the other genotypes, whereas the content of $\mathrm{C} 18: 0$ was significantly higher in the SF $50 \mathrm{CH} 50$ crossbreds. The C16:0 made up the greatest proportion of SFA both in the SF 75 CH 25 and IW type lambs, which was in agreement with POPOVA (2007). In this experiment, meat from lambs always comprised the highest proportion of C16:0 from SFA in anatomically different muscles and/or different rearing systems. Similar results were also discovered by JOY et al. (2008) in lambs and by WARREN et al. (2008) in cattle. In our experiment, the highest proportion of C18:0 from all SFA in the SF $50 \mathrm{CH} 50$ crossbreds most likely points to a different potential of this genotype to synthesize diverse proportions of a particular SFA. It has been reported that different dietary SFA have different physiological effects. SFA influence plasma cholesterol, though C18:0 is considered neutral in this regard (DIETSCHY 1998) and C12:0, C14:0 and C16:0 are hypercholesterolemic (YU et al. 1995). In addition, YU et al. (1995) suggested that C14:0 is 5-6 times more atherogenic, or hyper-cholesterolaemic, than either $\mathrm{C} 12: 0$ or $\mathrm{C} 16: 0$. Thus, the meat from SF $75 \mathrm{CH} 25$ lambs in our experiment contained a less desirable proportion of particular SFA with respect to human health. MARINO et al. (2008) found that when the slaughter weight of lambs increased, the FA composition changed because of an increased proportion of SFA, which doesn't correspond with our results. In contrast, the significantly lower LWS of the SF 75 $\mathrm{CH} 25$ crossbreds in our experiment displayed a higher proportion of total SFA. 
Concerning MUFA, the genotype significantly affected the content of C16:1. In the case of different methods of crossing between SF and $\mathrm{CH}$ breeds, there was also observed a lower proportion of C18:1 in SF 75 CH 25 lambs, compared to SF 50 CH 50 lambs. Generally the C18:1 comprised the greatest proportion out of the observed FA in all genotypes, which is in agreement with POPOVA (2007). The enzyme responsible for the conversion of all SFA to their respective MUFA, as well as trans-vaccenic acid to rumenic acid (cis-9, trans-11 CLA), is $\Delta^{9}$-desaturase (HAUSMAN et al. 2009). As for ruminants, fatty acids in the feed are chemically reduced by microorganisms in the rumen and absorbed as saturated fatty acids. The composition of FA stored in the fat depots reflects the previous action of $\Delta^{9}$-desaturase on substrates such as C18:0 or C16:0 (KIM and NTAMBI 1999, YANG et al. 1999). Given its determinant role in fatty acid oxidation, $\Delta^{9}$-desaturase is a candidate for genetic variation in fatty acid composition (TANIGUCHI et al. 2004b). In our study, a lower value of $\Delta^{9}$-desaturase (16) index was found in the SF $50 \mathrm{CH} 50$ crossbreds compared to the SF $75 \mathrm{CH} 25$ and IW type lambs, when the values of $\Delta^{9}$-desaturase (18) index did not vary among the Suffolksired genotypes. Similarly ZAPLETAL et al. (2009) found out the differences in values of $\Delta^{9}$ desaturase (16) index in phylogenetically related breeds of cattle, while their $\Delta^{9}$-desaturase (18) index did not differ. TANIGUCHI et al. (2004a) reported that the stearoyl-CoA desaturase (SCD) mRNA expression level was related to the MUFA percentage in cattle and described single nucleotide polymorphism, which contributed to a higher MUFA percentage and a lower melting point in IM fat. According to TANIGUCHI et al. (2004b) the sterol regulatory element binding proteins (SREBP) may have a certain effect on FA composition and the fat melting point via transcription activation of the SCD expression level in cattle. Likewise, HOASHI et al. (2007) demonstrated that the bovine SREBP-1 polymorphism was associated with MUFA proportion in the composition.

The total content of PUFA was not affected by genotype. However IW genotype showed higher contents of C18:2-n6, C20:4-n6, C22:4-n6 and total n-6 PUFA proportion compared to the SF 50 CH 50 genotype. Generally, the $n-6 / n-3$ PUFA ratio set for human nutrition is 4-5 $\leq 1$ of dietary fat (SIMOPOULOS 2002, GERMAN SOCIETY OF HUMAN NUTRITION 2004). In our experiment, meat from all Suffolk-sired crossbreds contained the favorable ratio of n-6/n-3 FA, while a significantly lower value was found in the SF $50 \mathrm{CH} 50$ lambs (1.82) compared to the IW type lambs (1.98). DE SMET et al. (2004) pointed out that the $n-6 / n-3$ ratio of the total lipid fraction of muscle may vary depending on the $n-6 / n-3$ ratio of the phospholipid and triacylglycerol fractions though this ratio is much more affected by the feeding regimes of the animals than by genetics. The authors also suggest that no general relationship between the level of fatness and the $n-6 / n-3$ ratio in the meat can be expected due to the overriding effect of the dietary $n-6 / n-3$ ratio, which corresponds with our findings relating to the IM fat content of different Suffolk-sired genotypes $(P \geq 0.05)$. The minimum $\mathrm{P} / \mathrm{S}$ ratio set for human nutrition is at least 0.45 (SIMOPOULOS 2004) and generally should be around 0.7 (RAES et al. 2003). If fat from ruminant meat is highly saturated, it is considered to have detrimental effects on human health (MONTEIRO et al. 2006). Generally, reducing the intake of SFA (which are known to raise the total and LDL cholesterol) and increasing the intake of n-3 PUFA is particularly encouraged (WHO 2003). In our experiment, a significantly higher value of $\mathrm{P} / \mathrm{S}$ ratio was found in IW type lambs compared to the SF 50 CH 50 genotype. Generally the P/S ratio of the Quadriceps femoris muscle in our experiment fluctuated from 
0.20 to 0.24 which corresponds to the findings of ORIANI et al. (2005) and BRZOSTOWSKI et al. (2006). Moreover, ORIANI et al. (2005) observed a significantly higher P/S ratio in the Semimembranosus muscle compared to the Quadriceps femoris and Longissimus dorsi muscles. Conversely, a higher $\mathrm{P} / \mathrm{S}$ ratio was presented by MARINO et al. (2008) found in the longissimus dorsi muscle of Altamurana and Trimeticcio lambs. SCOLLAN et al. (2003) also pointed out association between fatness and P/S ratio. According to previous authors the content of SFA and MUFA increases more rapidly with increased fatness in cattle, than does the content of PUFA. However, in our case, a tendency towards a higher proportion of IM fat in SF 75 CH 25 lambs $(P \geq 0.5)$ did not lead to a lower $P / S$ ratio in muscle. Fatty acids can promote or prevent atherosclerosis and coronary thrombosis based on their effects on serum cholesterol and low-density lipoprotein-cholesterol concentrations (MARINO et al. 2008). Favourable lower Al and TI, in our experiment, were found in the IW crossbreds, which would indicate a lower risk of atherosclerosis and coronary thrombosis as a result of consuming this particular type of meat. Likewise, SALVATORI et al. (2004) observed the effect of genotype on the differing values of $\mathrm{Al}$ in all of the evaluated muscles of crossbred lambs. In our experiment, the values of Al and TI were lower, compared to the results published by SALVATORI et al. (2004) or ORIANI et al. (2005).

Generally, the findings concerning the FA composition of Suffolk-sired crossbreds in our experiment confirmed the opinion of LABORDE et al. (2001), that certain breeding methods may be used in order to improve the FA composition of intramuscular fat with regard to human consumption and health.

In conclusion, our experiment revealed a major effect of the Suffolk-sired genotype on the fatty acid profile of the Quadriceps femoris muscle. Lambs of the IW genotype had a lower saturated fatty acids proportion and lower values of atherogenic and thrombogenic indexes and a higher $\mathrm{P} / \mathrm{S}$ ratio in their meat than lambs of the $\mathrm{CH}$ genotypes. This resulted in better nutritional characteristics of their meat with regard to human health. As for crossing between the Suffolk and Charollais breeds, a favourable fatty acids profile of meat was observed in the F1 crossbred as compared to the F11 crossbred.

\section{Acknowledgements}

This study was supported by the Research plan No. MSM 2B06108.

\section{References}

Angood KM, Wood JD, Nute GR, Whittington FM, Hughes SI, Sheard PR (2008) A comparison of organic and conventionally-produced lamb purchased from three major UK supermarkets: Price, eating quality and fatty acid composition. Meat Sci 78, 176-84

Archimede H, Pellonde P, Despois P, Etienne T, Alexandre G (2008) Growth performances and carcass traits of Ovin Martinik lambs fed various ratios of tropical forage to concentrate under intensive conditions. Small Rumin Res 75, 162-70

Bianchi G, Garibotto G, Bentancour O (2003) Growth characteristics of light lambs sired by Corriedale, Texel, Hampshire Down, Southdown, lle de France, Milchschaf or Suffolk rams with Corriedale ewes. Arch Zootec 52, 339-45

Borys B, Borys A, Przegalinska-Gorczkowska M (2007) Level of fatty acids in adipose tissue of lambs with regard to breed origin and sex. Ann Anim Sci 7, 99-111 
Brzostowski H, Niznikowski R, Milewski S (2006) Composition and properties of meat of Pomeranian purebred lambs and their crossbreeds with Berrichon du Cher and Charolaise. Arch Tierz 49, 494-501

Cifuni GF, Braghieri A, Riviezzi AM, Girolami A, Napolitano F (2003) Artificial rearing and intramuscular fatty acid composition of unweaned lambs. Ital J Food Sci 15, 241-8

Da Cunha EA, Santos LE, Bueno MS, Roda DS, Leinz FF, Rodrigues CFC (2000) Use of meat sheep sire breed on fine wool ewe flocks to produce fast-growing lambs for slaughter. R Bras Zootec 29, 243-52

De Smet S, Raes K, Demeyer D (2004) Meat fatty acid composition as affected by fatness and genetic factors: a review. Anim Res 53, 81-98

Dietschy JM (1998) Dietary fatty acids and the regulation of plasma low density lipoprotein cholesterol concentrations. J Nutr 128, 444-8

Fantová M, Čislíkovská H (1991) The effect of breed on meat quality in lambs reared on pasture shared with their mothers. Živoč Výr 36, 633-40

Food Advisory Committee (1990) Report on Review of Food Labelling and Advertising. Her Majesty's Stationery Office, London

Foti F, Caparra P, Scerra M, Vottari G, Cilione C, Scerra V (2005) Influence of ewe feeding systems on meat quality of suckling lambs. Ital J Anim Sci 4, 354-6

Gruszecki TM, Junkuszew A, Lipecka CZ, Kaminska A, Szymanowska A, Patkowski K (2004) Fatty acids composition in sheep milk and muscle tissue of lamb fed protective fat-supplemented fodder. Arch Tierz 47, $183-8$

Gutiérrez J, Rubio MS, Méndez RD (2005) Effects of crossbreeding Mexican Pelibuey sheep with Rambouillet and Suffolk on carcass traits. Meat Sci 70, 1-5

Hausman GJ, Dodson MV, Ajuwon K, Azain M, Barnes KM, Guan LL, Jiang Z, Poulos SP, Sainz RD, Smith S, Spurlock M, Novakofski J, Fernyhough ME, Bergen WG (2009) The biology and regulation of preadipocytes and adipocytes in meat animals. J Anim Sci 87, 1218-46

Hoashi S, Ashida N, Ohsaki H, Utsugi T, Sasazaki S, Taniguchi M, Oyama K, Mukai F, Mannen H (2007) Genotype of bovine sterol regulatory element binding protein-1 (SREBP-1) is associated with fatty acid composition in Japanese Black cattle. Mamm Genome 18, 880-6

Joy M, Ripoll G, Delfa R (2008) Effects of feeding system on carcass and non-carcass composition of Churra Tensina light lambs. Small Rumin Res 78, 123-33

Kim YC, Ntambi JM (1999) Regulation of stearoyl-CoA desaturase genes: role in cellular metabolism and preadipocyte differentiation. Biochem Biophys Res Commun 266, 1-4

Kremer R, Barbatto G, Castro L, Rista L, Rosés L, Herrera V, Neirotti V (2004) Effect of sire breed, year, sex and weight on carcass characteristics of lambs. Small Rumin Res 53, 117-24

Kuchtík J, Horák F (2001) Growth ability, carcass and meat quality of lambs of the German Long-wooled sheep and their crosses. Czech J Anim Sci 46, 439-48

Kuchtík J, Šubrt J, Horák F (1996) Quality analysis of meat of slaughter lambs. Živoč Výr 41, 183-8

Laborde FL, Mandell IB, Tosh JJ, Wilton JW, Buchanan-Smith JG (2001) Breed effects on growth performance, carcass characteristics, fatty acid composition, and palatability attributes in finishing steers. J Anim Sci 79, 355-65

Marino R, Albenzio M, Annicchiarico G, Caroprese M, Muscio A, Santillo A, Sevi A (2008) Influence of genotype and slaughtering age on meat from Altamurana and Trimeticcio lambs. Small Rumin Res 78, 144-51

Monteiro ACG, Santos-Silva J, Bessa RJB, Navas DR, Lemos JPC (2006) Fatty acid composition of intramuscular fat of bulls and steers. Livest Sci 99, 13-9

Nutrition report of the German Society of Human Nutrition (DGE) (2004) DGE, Bonn, 63

Nürnberg K, Ender B, Papstein HJ, Wegner J, Ender K, Nürnberg G (1999) Effects of growth and breed on the fatty acid composition of the muscle lipids in cattle. Z Lebensm Unters Forsch A 208, 332-5

Nürnberg K, Gumbach S, Nürnberg G, Hartung M, Zupp W, Ender K (2001) Influence of breed and production system on meat quality and fatty acid composition in lamb muscle. Arch Tierz 44, 351-60 
Nürnberg K, Wegner J, Ender K (1998) Factors influencing fat composition in muscle and adipose tissue of farm animals. Livest Prod Sci 56, 145-56

Nürnberg K, Zupp W, Grumbach S, Martin J, Ender K, Hartung M, Nürnberg G (2006) Does feeding under organic farming conditions affect the meat and fat quality of finishing lambs? Fleisch 86, 103-7

Oriani G, Maiorano G, Filetti F, Di Cesare C, Manchisi A, Salvatori G (2005) Effect of age on fatty acid composition of Italian Merino suckling lambs. Meat Sci 71, 557-62

Popova T (2007) Effect of the rearing system on the fatty acid composition and oxidative stability of the M. longissimus lumborum and M. semimembranosus in lambs. Small Rumin Res 71, 150-7

Raes K, Balcaen A, Dirinck P, De Winne A, Claeys E, Demeyer D, DeSmet S (2003) Meat quality, fatty acid composition and flavour analysis in Belgian retail beef. Meat Sci 65, 1237-46

Salvatori G, Pantaleo L, Di Cesare C, Maiorano G, Filetti F, Oriani G (2004) Fatty acid composition and cholesterol content of muscles as related to genotype and vitamin E treatment in crossbred lambs. Meat Sci 67, 45-55

Scollan ND, Enser M, Gulati S, Richardson RI, Wood JD (2003) Effect of including a ruminally protected lipid supplement in the diet on the fatty acid composition of beef muscle in Charolais steers. Br J Nutr 90, 709-16

Simopoulos AP (2002) The importance of the ratio of omega-6/omega-3 essential fatty acids. (Dosier: Polyunsaturated fatty acids in biology and diseases). Biomed Pharmacother 56, 365-79

Simopoulos AP (2004) Omega-6/Omega-3 essential fatty acid ratio and chronic diseases. Food Rev Int 20, 77-90

Snowder GD, Duckett SK (2003) Evaluation of the South African Dorper as a terminal sire breed for growth, carcass, and palatability characteristics. J Anim Sci 81, 368-75

Szumacher-Strabel M, Potkanski A, Cieslak A (2001) Effect of protected fatty acid composition and conjugated linoleic acid level in meat and milk of sheep. Arch Tierz 44 Special Issue, 329-35

Taniguchi M, Mannen H, Oyama K, Shimakura Y, Oka A, Watanabe H, Kojima T, Komatu A, Harper GS, Tsuji S (2004a) Differences in stearoyl-CoA desaturase mRNA levels between Japanese Black and Holstein cattle. Livest Prod Sci 87, 215-20

Taniguchi M, Utsugi T, Oyama K, Mannen H, Kobayashi M, Tanabe Y, Ogino A, Tsuji S (2004b) Genotype of stearoyl-CoA desaturase is associated with fatty acid composition in Japanese Black cattle. Mamm Genome 15, 42-148

Ulbricht TLV, Southgate DAT (1991) Coronary heart disease: seven dietary factors. Lancet 338, 985-92

Warren HE, Scollan ND, Enser M, Hughes SI, Richardson RI, Wood JD (2008) Effects of breed and a concentrate or grass silage diet on beef quality in cattle of 3 ages. I: Animal performance, carcass quality and muscle fatty acid composition. Meat Sci 78, 256-69

WHO (2003) Diet, nutrition and the prevention of chronic diseases. Report of a joint WHO/FAO expert consultation. WHO technical report series 916 , Geneva.

Yang A, Larsen TW, Smith SB, Tume RK (1999) D9 desaturase activity in bovine subcutaneous adipose tissue of different fatty acid composition. Lipids 34, 971-8

Yu S, Derr J, Etherton TD, Kris-Etherton PM (1995) Plasma cholesterol-predictive equations demonstrate that stearic acid is neutral and monosaturated fatty acids are hypocholesterolemic. Am J Clin Nutr 61, 1129-39

Zapletal D, Chládek G, Šubrt J (2009) Breed variation in the chemical and fatty acid compositions of the longissimus dorsi muscle in Czech Fleckvieh and Montbeliarde cattle. Livest Sci 123, 28-33

Received 8 December 2009, accepted 21 July 2010.

Corresponding author:

DAVID ZAPLETAL

email: zapletald@vfu.cz

Department of Nutrition, Animal Husbandry and Animal Hygiene, Faculty of Veterinary Hygiene and Ecology University of Veterinary and Pharmaceutical Sciences Brno, Palackého 1-3, 61242 Brno, Czech Republic 